Second draft - please do not cite or quote

\title{
The Amenity Value of the Italian Climate
}

\author{
by
}

David Maddison and Andrea Bigano

1 The authors are with the Centre for Social and Economic Research on the Global Environment (CSERGE), University College London / University of East Anglia and the Centre for Economic Studies (CES), University of Leuven respectively. CSERGE is a designated research centre of the UK Economic and Social Research Centre (ESRC). Both authors would like to thank Marilena Pollicino, Giovanna Meregalli, Mikki Byskup and Barbara Sianesi for their research assistance. 


\begin{abstract}
The hedonic price literature suggests that locations with more favourable characteristics should display compensating wage and house price differentials. Estimates of the marginal willingness to pay for small changes in climate variables are derived using the hedonic price technique applied to Italian data. A hedonic price model was specified in terms of January and July averages. There exists considerable empirical support for the hypothesis that amenity values for climate are embedded in the labour and housing market. Italians would prefer a drier climate during the winter months, but higher summertime temperatures are shown to reduce welfare. These results may have relevance to the task of determining the economic impact of future climate change.
\end{abstract}




\section{Introduction}

Climate is an important input to many household activities. Climate influences our health and determines our heating or cooling requirements, clothing and nutritional needs. Climate also constrains recreational and leisure activities and particular types of climate are known to promote a psychological sense of wellbeing. All this explains why households living in climatically different regions are likely to consume different patterns of marketed commodities: it is to compensate for, or alternatively take advantage of particular types of climate.

But if at the same time as being free to adjust patterns of demand individuals are also freely able to select from differentiated localities then climate itself becomes a choice variable. The tendency will be for the costs and benefits associated with particular climates to become capitalised into property prices and wages. Thus across different locations there must generally exist both compensating wage and house price differentials and in such cases the value of marginal changes in climate can be discerned from hedonic house and wage price regressions.

Possessing a money metric measure of the impact of changes in climate on welfare may prove especially useful given the question about whether the costs of preventing climate change are justified by the benefits. The main advantage of using the hedonic technique to deduce the value of climate variables is that since one is in effect using current day analogues for future climate change it can be presumed that long run cost minimising adaptation has already occurred ${ }^{2}$. Apart from its strong theoretical underpinnings it is in this sense that the hedonic technique possesses particular appeal.

There are however very few hedonic analyses of the amenity value of climate. Much of what is known about amenity values actually comes from studies in which the inclusion of climate variables is incidental to the main purpose of the analysis. Furthermore and to the best of our knowledge, outside of the United States there is a complete lack of published studies on the household amenity value of climate.

This paper is an attempt at determining whether the hedonic markets for housing or labour in Italy are significantly impacted by the climate. Italy's geographic and topographic characteristics combined with the influences of the seas that

\footnotetext{
${ }^{2}$ Although anthropogenically induced climate change is predicted to occur at a geologically unprecedented rate it is still relatively slow compared to the lifetime of households.
} 
surround it lead to a marked variation in climate and it is this feature of Italy that makes it a particularly suitable country to analyse.

In Alpine Italy (Valle d'Aosta and Trentino) the climate is similar to that of Switzerland or Austria. Winter is bitterly cold but is perversely the driest season. Further south Lombardy and Emilia Romagna have a typically continental type climate with cold winters and hot summers. The Po Valley is famous for the fogs that envelop the region for days on end disrupting flights into Milan and Verona airports. In Liguria and Tuscany a typically Mediterranean type climate prevails with mild winters and hot and dry, summers. Meanwhile in Calabria and Sicily the climate is characterised by a dry, sunny and extremely hot summer. Sometimes the temperature in Sicily in July exceeds 40 degrees centigrade.

We believe this to be the first application of the hedonic technique in Italy. But apart from the geographical domain of application this study possesses a number of other features that distinguish it from earlier studies. It uses climate data at a high geographical resolution and includes a wider range of climate variables. It explores the use of seasonal rather than annual averages for climate variables and carefully investigates the potential significance of higher-order terms. It also includes controls for geographic and topographic variables that are seen to have a considerable impact on estimated amenity value of climate.

The remainder of this paper is organised as follows: the next section reviews existing evidence on the amenity value of climate as indicated in the hedonic literature. In the third section the data sources for the exercise are discussed. The fourth section reports on the econometric results of the hedonic analysis. Using these hedonic regressions the paper then in section five computes a set of implicit prices showing the welfare effects of marginal changes in the level of climate amenities. The final section concludes. 


\section{Hedonic studies into the amenity value of climate.}

The hedonic approach asserts that if individuals are freely able to select from differentiated localities then the tendency will be for the costs and benefits associated with disamenities to become capitalised into house prices and wage rates. Households are attracted to regions offering preferred combinations of amenities and this inward migration both increases house prices within those cities as well as depressing wage rates. Thus across different cities there must generally exist both compensating wage and house price differentials and the value of marginal changes can be discerned from hedonic house and wage price regressions. Palmquist (1991) gives a general overview of the hedonic technique.

The hedonic methodology of course rests on a number of well-known assumptions. These include assumptions regarding the existence of equilibrium in the hedonic markets, perfect information and the absence of relocation costs. The model also relies upon the existence of smoothly continuous trade-off possibilities among all characteristics. This is necessary for households to be able to locate at a position of simultaneous equilibrium with respect to all characteristics rather than being located at a 'corner' solution (Maler, 1977). Finally, the technique assumes the existence of a unified market for land and labour. If geographically segmented markets exist then pooling of the data might lead to biased coefficients in the hedonic price equations since a single regression line is fitted to what are effectively two or more spline-functions (Strazheim, 1974).

These assumptions do not appear unreasonable in the context of hedonic studies of the climate. Provided that the extent of disequilibrium is not correlated with the level of any of the environmental amenities this will not result in biased coefficients in the hedonic price regression ${ }^{3}$. It further seems implausible that relocation costs could prevent the amenity costs of climate from being reflected in hedonic markets. Society has had a considerable length of time to respond to differences in climate - far longer in fact than the lifetime of any household. It would also be hard to argue that ignorance or misperceptions concerning regional variations in climate undermine the use of the hedonic technique. The assumption of continuously varying levels of climate variables also seems warranted. The assumption of geographically unified markets for land and labour however seems more doubtful given the geographic distances over which climate is apt to vary.

\footnotetext{
${ }^{3}$ Such risks are diminished even further as we shall go on to analyse a panel of data extending over a period of 5 years.
} 
Fortunately this is an assumption that can be tested for by estimating hedonic price regressions over sub-samples of data.

A number of researchers have analysed the amenity value of climate to United States households using the hedonic technique although most have included climate variables for reasons incidental to the main purpose of the analysis. Hoch and Drake (1974) analysed the wages paid to three worker categories. Climate was specified in terms of precipitation, summer and winter temperatures, wind speed, degree-days, snowfall and the number of very hot and very cold days. The first attempt to estimate the effects of climate on both wages and house prices together is Roback (1982). Her analysis included snowfall, degree-days, cloudy days and clear days. These variables are all highly significant and their coefficients have the expected sign in the wages regression but performed poorly in the rental price regressions.

In his analysis Smith (1983) used 'real' wages as the dependent variables and employed a regional cost of living index as a deflator. Hours of sunshine, high and low temperatures, annual average wind speed and precipitation were among the site-specific characteristics considered. Only sunshine proved to have a significant effect. Hoehn et al (1987) estimates separate hedonic regressions for wages and housing expenditures. They controlled for structural characteristics of houses and individual characteristics of workers. The same amenity variables were used in both equations and included sunshine, precipitation, humidity, wind speed, heating and cooling degree-days. Apart from wind speed and heating degree-days these variables are all significant.

Englin (1996) investigates the amenity value of rainfall using two alternative measures: long term annual average rainfall and the variation of rainfall. Englin finds that households prefer less rainfall to more but that holding annual rainfall constant households prefer a greater seasonal variation in rainfall. Finally, in what is probably the most advanced analysis undertaken so far, Nordhaus (1996) attempts to explain nominal wages corrected for differences in the cost of living in the United States. Variations in the dependent variable are explained by reference to January, April, July and October averages for temperature and precipitation, population density, demographic variables and the presence of major bodies of water. A fixed-effects model is estimated to account for the presence of state-specific effects including tax structures and the level of public 
goods. Unfortunately shortcomings in the data seem to prevent the author from placing much faith in his estimates ${ }^{4}$.

The analysis for Italy presented in this paper is similar in spirit to the one undertaken by Nordhaus but with arguably improved data and different control variables. Furthermore it deals with a country where climate varies substantially over a relatively small area - something that is likely to be important for successful application of the hedonic technique ${ }^{5}$.

\footnotetext{
${ }^{4}$ Recently Cragg and Kahn (1997) and Cragg and Kahn (1999) offer an approach somewhat different to earlier hedonic analyses. They estimate the demand for climate in the US based on the locational choice of migrants. Hours of sunshine, annual rainfall, humidity and February and July temperatures are included in their analysis. There are also several studies of migration which, although lacking a welfare-theoretic basis, show that migrants are alternately attracted and repelled by particular sorts of climate (e.g. Graves, 1980 and Cushing, 1987).

${ }^{5}$ Italy is comparable in size to the state of Arizona. The migration studies referred to in the preceding note assume a homogenous climate at the state level.
} 


\section{Data sources}

A survey of provincial property prices per square metre is taken from Il Sole 24 Ore (a leading financial newspaper in Italy). This series is used to adjust nationally averaged annual household expenditure on housing. Provincial data on expected labour income per worker is taken from the Istituto Nazionale Previdenza Sociale (the National Institute for Social Security) or INPS for short. Note that if unemployment is high in a particular province then the probability of employment (and therefore expected labour income per worker) will be low ${ }^{6}$. This series is used to adjust nationally averaged annual after tax household income derived from labour. Housing expenditures are then subtracted from after tax labour income to yield 'net household income'. Note that this procedure differs from the more usual practice of estimating separate regressions for wage rates and housing costs per square metre. This is appropriate where individuals are able to adjust their hours of employment or economise on floor space. In the case of Italy however only 19 percent of workers report being able to adjust the number of hours that they work (Banca d'Italia, 2000) and data on how average dwelling size varies across the provinces is not available. Data are available for each of the 95 provinces of Italy from 1991 to 1995 making 475 observations available for analysis.

The climate data is taken from Leemans and Cramer (1991). This database merges records drawn from a variety of published sources. After various checks for quality and reliability Leemans and Cramer create a terrestrial grid at the $0.5^{\circ}$ level of resolution. Only mean temperature, precipitation and the fraction of the sky clear of cloud are included in the data set and these are reported as monthly averages. Temperatures are adjusted so that they correspond to the average elevation of each province. This is a fundamental adjustment. Note carefully that the 'fraction of clear sky' is not measuring quite the same thing as 'hours of sunshine' This is because the fraction of clear sky is calculated over both day and night

Apart from climate a number of other amenity variables were included in the analysis. A dummy variable was used to identify those provinces bordering on

\footnotetext{
${ }^{6}$ Unemployment varies markedly across Italy being much higher in the south than in the north. Some provinces in Sicily have unemployment rates exceeding 30 percent. Other provinces along the Swiss border have unemployment rates of slightly over 1 percent.

${ }^{7}$ Leemans and Cramer indicate that the data for the fraction of clear sky is of a lower quality than that for precipitation and temperature.
} 
the sea. Another dummy variable identifies the alpine regions of Italy 8 . Latitude and longitude are also included as additional controls ${ }^{2}$. Population density is included but is treated as a potentially endogenous variable (see Steinnes and Fisher, 1974). Following Nordhaus (1996) population density is instrumented using provincial data on the presence of military personnel as the instrumental variable 10 .

In order to guard against the possibility of segmented markets Italy was divided into five different regions. These regions are Northern Italy (Liguria, Friuli, Trentino, Veneto, Valle d'Aosta, Emilia Romagna, Lombardy and Piemonte); Central Italy (Abruzzo, Umbria, Marche, Tuscany and Lazio); Southern Italy (Calabria, Basilicata, Puglia, Molise and Campagnia); Sardinia; and Sicily (see figure 1). Many hedonic analyses have also treated the market as defined by the boundary of major metropolitan areas. In order to explore the possibility of submarkets for the major metropolitan areas in Italy (the provinces of Milan, Rome, Naples and Turin are distinct in terms of their size) four additional dummy variables were created. Four dummy variables were also used to denote data drawn from different years.

\footnotetext{
${ }^{8}$ The alpine regions of Italy (Valle d'Aosta, Belluno, Bolzano, Trentino and Sondrio) include those provinces with an average elevation exceeding 1,000 metres.

${ }^{9}$ Including latitude and longitude might not seem such a good idea. In particular, the correlation between latitude and January temperatures is -0.83 . At the same time however latitude is correlated with hours of daylight. Furthermore it may be that distance from a fixed location (e.g. Rome or Italy's 'centre of gravity') is an important amenity.

10 The idea here is that military personnel are stationed in particular areas for reasons unconnected with attractive net labour incomes. We have provincial level information on army bases, naval bases and military air bases.
} 
Table 1: Definition of variables included in the data set

$\begin{array}{ll}\text { Variable } & \text { Definition } \\ \text { NETINC } & \text { After tax labour income net of housing costs (millions of Lira) } \\ \text { JANPRECIP } & \text { Average precipitation in January }(\mathrm{mm}) \\ \text { JULPRECIP } & \text { Average precipitation in July }(\mathrm{mm}) \\ \text { JANTEMP } & \text { Average mean temperature in January }\left({ }^{\circ} \mathrm{C}\right) \\ \text { JULTEMP } & \text { Average mean temperature in July }\left({ }^{\circ} \mathrm{C}\right) \\ \text { JANCLEAR } & \text { Average fraction of clear sky in January } \\ \text { JULCLEAR } & \text { Average fraction of clear sky in July } \\ \text { COAST } & \text { Unity if the province borders on the sea, zero otherwise } \\ \text { ALPINE } & \text { Unity if the province is in the Alps, zero otherwise } \\ \text { POPDEN } & \left.\text { Population density of the province (persons per km }{ }^{2}\right) \\ \text { LAT } & \text { Latitude } \\ \text { LONG } & \text { Longitude } \\ \text { MILAN } & \text { Unity if the province is Milan, zero otherwise } \\ \text { ROME } & \text { Unity if the province is Rome, zero otherwise } \\ \text { NAPLES } & \text { Unity if the province is Naples, zero otherwise } \\ \text { TURIN } & \text { Unity if the province is Turin, zero otherwise } \\ \text { CENTRAL } & \text { Unity if the province is in Central Italy, zero otherwise } \\ \text { SOUTH } & \text { Unity if the province is in Southern Italy, zero otherwise } \\ \text { SARDINIA } & \text { Unity if the province is in Sardinia, zero otherwise } \\ \text { SICILY } & \text { Unity if the province is in Sicily, zero otherwise } \\ \text { DUM92 } & \text { Unity if the year is 1992, zero otherwise } \\ \text { DUM93 } & \text { Unity if the year is 1993, zero otherwise } \\ \text { DUM94 } & \text { Unity if the year is 1994, zero otherwise } \\ \text { DUM95 } & \text { Unity if the year is 1995, zero otherwise }\end{array}$

Source: Leemans and Cramer (1991), INPS, and Il Sole 24 Ore del Lunedi (1991, 1992, 1993, 1994 and 1995). 
Table 2: Characteristics of the 95 Italian provinces

$\begin{array}{lllll}\text { Variable } & \text { Mean } & \text { Std. Dev. } & \text { Minimum } & \text { Maximum } \\ \text { NETINC } & 17.5 & 2.3 & 9.3 & 24.6 \\ \text { JANPRECIP } & 86 & 36 & 32 & 230 \\ \text { JULPRECIP } & 36 & 31 & 1 & 149 \\ \text { JANTEMP } & 4.1 & 3.8 & -7.3 & 10.9 \\ \text { JULTEMP } & 22.7 & 3.0 & 9.3 & 26.2 \\ \text { JANCLEAR } & 0.38 & 0.05 & 0.27 & 0.50 \\ \text { JULCLEAR } & 0.66 & 0.07 & 0.46 & 0.81 \\ \text { COAST } & 0.56 & 0.50 & 0 & 1 \\ \text { ALPINE } & 0.05 & 0.22 & 0 & 1 \\ \text { POPDEN } & 238 & 325 & 36 & 2662 \\ \text { LAT } & 4262 & 263 & 3650 & 4600 \\ \text { LONG } & 1190 & 258 & 700 & 1800 \\ \text { MILAN } & 0.01 & 0.10 & 0 & 1 \\ \text { ROME } & 0.01 & 0.10 & 0 & 1 \\ \text { NAPLES } & 0.01 & 0.10 & 0 & 1 \\ \text { TURIN } & 0.01 & 0.10 & 0 & 1 \\ \text { CENTRAL } & 0.25 & 0.25 & 0 & 1 \\ \text { SOUTH } & 0.18 & 0.18 & 0 & 1 \\ \text { SARDINIA } & 0.04 & 0.04 & 0 & 1 \\ \text { SICILY } & 0.09 & 0.09 & 0 & 1 \\ \text { DUM92 } & 0.20 & 0.40 & 0 & 1 \\ \text { DUM93 } & 0.20 & 0.40 & 0 & 1 \\ \text { DUM94 } & 0.20 & 0.40 & 0 & 1 \\ \text { DUM95 } & 0.20 & 0.40 & 0 & 1\end{array}$

Source: Leemans and Cramer (1991), INPS and Il Sole 24 Ore del Lunedi (1991, 1992, 1993, 1994, and 1995). 
Figure 1: The regions of Italy 
Source: See text. 


\section{Empirical analysis}

In what follows hedonic regressions on net household incomes are undertaken using January and July averages rather than annual averages. This permits us to investigate whether, as might be expected, the amenity value of a marginal increase in the level of particular climate amenities depends on which season it falls into. The variables describing climate (as well as all the other non-binary variables) are entered as both linear and quadratic variables. As is customary the means of the variables were subtracted prior to squaring them in order to reduce potential multicollinearity. Using the method described by Maddala (1977) three different transformations of the dependent variable were examined: the linear, semilog and inverse models. The linear model was found most likely to have generated the observed data.

The regression analyses manage to explain 64 percent of the variation in net household income (see table 3). Note that the standard errors of the parameter estimates have been corrected to account for the likely correlation of residuals when observations are drawn repeatedly from the same province ${ }^{11}$. These standard errors are also robust in the presence of heteroskedasticity. Note thata Hausman test fails to reject the hypothesis that population density is exogenous ${ }^{12}$. Because of this finding population density has not been instrumented in the results shown.

In the regression equation four climate variables are significant (two highly so). The latitude and longitude variables are all statistically significant suggesting that Italians have strong preferences for geographic location quite independently of climatic and topographic variables. The variable indicating proximity to the coast is significant whilst the variable indicating whether the province is in the alpine region of Italy is highly significant. Proximity to the coast and the Alps are an amenity ${ }^{13}$. Controlling for latitude, longitude, topography and proximity to the coast appears to be very important. Without these additional controls the coefficients on the climate variables readily change sign.

\footnotetext{
${ }^{11}$ We are using Panel-Corrected Least Squares.

${ }^{12} \chi^{2}(20)=0.76$ which is not significant.

${ }_{13}$ Part of alpine Italy was annexed from Austria at the end of the First World War. Other parts of alpine Italy are French-speaking. Hence the variable ALPINE might also be seen as reflecting a degree of market segmentation.
} 
The dummy variables for three of the four urban areas in Italy are highly significant as are three of the dummy variables for the five different regions of Italy. These findings point to market segmentation. The coefficients on the terms in population density are highly significant and indicate that higher levels of population density are ultimately regarded as a disamenity - an almost universal finding. As expected the dummy variables denoting the different years are highly significant and show increasing levels of net labour income. 
Table 3: The results of the hedonic regression

Dependent variable $=$ NETINC

\begin{tabular}{|c|c|}
\hline $\begin{array}{l}\text { Parameter } \\
\text { CONST }\end{array}$ & $\begin{array}{l}\text { Coefficient } \\
109.4359 \\
(3.46)\end{array}$ \\
\hline JANTEMP & $\begin{array}{l}0.825204 \\
(1.32)\end{array}$ \\
\hline JANTEMP $^{2}$ & $\begin{array}{l}0.114957 \\
(0.48)\end{array}$ \\
\hline JULTEMP & $\begin{array}{l}0.355427 \\
(2.73)\end{array}$ \\
\hline JULTEMP $^{2}$ & $\begin{array}{l}0.210637 \\
(1.01)\end{array}$ \\
\hline JANPRECIP & $\begin{array}{l}0.0338616 \\
(2.60)\end{array}$ \\
\hline JANPRECIP $^{2}$ & $\begin{array}{l}-0.001205 \\
(-1.29)\end{array}$ \\
\hline JULPRECIP & $\begin{array}{l}0.415362 \\
(1.25)\end{array}$ \\
\hline JULPRECIP $^{2}$ & $\begin{array}{l}-0.003399 \\
(-1.44)\end{array}$ \\
\hline JANCLEAR & $\begin{array}{l}-11.97623 \\
(-1.19)\end{array}$ \\
\hline JANCLEAR $^{2}$ & $\begin{array}{l}164.024 \\
(1.86)\end{array}$ \\
\hline JULCLEAR & $\begin{array}{l}-33.67762 \\
(-2.14)\end{array}$ \\
\hline JULCLEAR $^{2}$ & $\begin{array}{l}282.9566 \\
(2.90)\end{array}$ \\
\hline LAT & $\begin{array}{l}-0.171869 \\
(-2.89)\end{array}$ \\
\hline $\mathrm{LAT}^{2}$ & $\begin{array}{l}-0.00028 \\
(-2.68)\end{array}$ \\
\hline LONG & $\begin{array}{l}-0.07514 \\
(-3.22)\end{array}$ \\
\hline $\mathrm{LONG}^{2}$ & $\begin{array}{l}0.000109 \\
(2.81)\end{array}$ \\
\hline
\end{tabular}




$\begin{array}{ll}\text { COAST } & -0.880134 \\ & (-2.00) \\ \text { ALPINE } & -5.520199 \\ & (-3.62) \\ \text { ROME } & -1.455395 \\ & (-1.41) \\ \text { MILAN } & -7.880024 \\ & (-4.33) \\ \text { NAPLES } & -33.67878 \\ & (-3.42) \\ \text { TURIN } & -5.535101 \\ & (-10.65) \\ \text { POPDEN } & -0.0067318 \\ & (-3.33) \\ \text { POPDEN } & 8.07 \mathrm{E}-06 \\ & (3.38) \\ \text { CENTRAL } & -1.604921 \\ & (-1.44) \\ \text { SOUTH } & -4.756948 \\ & (-2.88) \\ \text { SARDINIA } & -9.699294 \\ & (-3.80) \\ \text { SICILY } & -6.327532 \\ & (-2.75) \\ \text { DUM92 } & 0.6742714 \\ & (12.66) \\ \text { DUM93 } & 0.7844456 \\ & (7.61) \\ \text { DUM94 } & 0.9398976 \\ & (7.95) \\ \text { DUM95 } & 1.959178 \\ & (19.06) \\ \text { R-Squared } & 0.640 \\ & \\ & \\ & \\ & \\ & \\ & \\ & \end{array}$

Source: Own calculations. T-statistics are in parentheses. 


\section{The implicit price of climate}

Differentiating the hedonic price function with respect to each of the climate variables and evaluating the derivative in a particular location yields a set of implicit prices specific to that location. We have calculated the implicit price of climate variables for Milan, Rome, Naples, Cagliari and Palermo. These are of course the largest cities in Northern Italy, Central Italy, Southern Italy, Sardinia and Sicily respectively. The implicit price of the climate variables is shown in table 4 where a negative sign denotes a disamenity.

In a number of instances households are shown to be paying statistically significant (even highly significant) sums of money to locate in areas with particular climates. In all five locations households are shown to dislike high levels of precipitation in January and high mean temperatures in July. Only in Milan however are households willing to pay a statistically significant amount for a marginal increase in the fraction of clear skies $\stackrel{44}{ }$.

These results seem plausible. High (frequently debilitating) July temperatures are the rule in Italy. And precipitation in January is hardly likely to be an amenity. The most interesting finding however is that whereas the Milanese would be willing to pay a significant amount to increase the fraction of clear skies in both January and July, people living in other locations would not. Here there is a correspondence between the unusual features of the Italian climate - the persistent fogs in the Po Valley - and the results of the analysis. By contrast the

remainder of Italy enjoys relatively clear skies ${ }^{15}$. Possibly the only surprising finding is that households in Milan would not pay a statistically significant sum to enjoy higher January temperatures (the parameter is unexpectedly signed but statistically insignificant).

The correspondence between known characteristics of the Italian climate and the results of the hedonic analysis is encouraging and supportive of the use of the methodology for the purposes of determining the amenity value of the climate. The empirical estimates indicate that even a small increase in July temperatures and precipitation in January could have an important effect on the cost of living

\footnotetext{
${ }^{14}$ Note that there is relatively high correlation of -0.92 between precipitation and the fraction of clear sky in July.

${ }^{15}$ Clear skies are associated with a high thermal excursion. They are also a contributory factor in ozone formation.
} 
in the whole of Italy ${ }^{16}$. These damage cost estimates are however based on the assumption that households do not move in response to increased July temperatures. To the extent that these households are able to relocate these are upper bound estimates (Bartik, 1988). Note finally that these implicit prices might also have picked up households' preferences for the fauna and flora associated with particular types of climate.

\footnotetext{
${ }^{16}$ For an equilibrium-doubling in carbon dioxide concentrations the general circulation model of the United Kingdom Meteorological Office predicts for Italy an increase in July temperatures of 2.5 degrees centigrade and an increase of 13 percent for precipitation in January.
} 
Table 4: Implicit prices for climate variables (000s of Lira / household / year)

$\begin{array}{llllll} & \text { Milan } & \text { Rome } & \text { Naples } & \text { Cagliari } & \text { Palermo } \\ \text { January Temperature } & -193 & -386 & -402 & -400 & -386 \\ \left({ }^{\circ} \mathrm{C}\right) & (-0.61) & (-1.44) & (-1.39) & (-1.40) & (-1.44) \\ \text { July Temperature } & -648 & -711 & -711 & -724 & -737 \\ \left({ }^{\circ} \mathrm{C}\right) & (-2.74) & (-2.71) & (-2.71) & (-2.69) & (-2.67) \\ \text { January Precipitation } & -42 & -33 & -26 & -37 & -30 \\ (\mathrm{~mm}) & (-2.24) & (-2.63) & (-3.24) & (-2.44) & (-2.89) \\ \text { July Precipitation } & -43 & -58 & -60 & -63 & -63 \\ (\text { mm) } & (-1.27) & (-1.46) & (-1.48) & (-1.50) & (-1.50) \\ \text { January Clear Skies } & 317 & -443 & 541 & -443 & -1427 \\ \text { (percentage point) } & (2.25) & (-0.31) & (-0.50) & (-0.31) & (-0.79) \\ \text { July Clear Skies } & 620 & 110 & 538 & -1725 & -2857 \\ \text { (percentage point) } & (3.06) & (0.69) & (0.33) & (-0.83) & (-1.21)\end{array}$

Source: Own calculations. T-statistics are in parentheses. 


\section{Conclusions}

There is considerable empirical support for the hypothesis that information on the amenity value of climate is contained in the market for housing and labour in Italy. That these findings emerge from such a small country and from a model in which a number of region-specific dummy variables have been included is all the more remarkable. It is similarly surprising that significant estimates emerge even when a range of climate variables are included as January and July averages rather than annual averages.

It appears that Italians regard the high July temperatures that they experience as a disamenity and similarly for high levels of precipitation in January. Insofar as future climate change is predicted to result in an increase in both it threatens to bring a considerable reduction in amenity values to Italian households.

Despite the moderately encouraging (from an academic perspective!) nature of the results the following qualifications are in order. First, the climate database did not include some relevant variables like wind speed, fog, snow, sunshine and humidity. Nor have we included information on the inter-annual variability of the climate. Second, the choice of explanatory variables is as always arbitrary, reflecting what was available rather than any other consideration. Thirdly, these results are acutely sensitive to whether or not geographical and topographical features are controlled for. Finally more work remains to be done on identifying the welfare impacts of non-marginal changes in climate and how these are affected by growth in household incomes. This is most important since climate change is not expected to become fully apparent until many years have elapsed. 


\section{References}

Banca d'Italia (2000) Supplementi al Bolletino Statistico: Note Metodologiche e Informazione Statistiche. I Bilanci delle Famiglie Italiane nell'Anno 1998. Banca d'Italia: Rome.

Bartik, T (1988) Measuring the Benefits of Amenity Improvements in Hedonic Price Models Land Economics Vol. 64 No. 2 pp172-183.

Cragg, M and Kahn, M (1997) New Estimates of Climate Demand: Evidence from Locational Choice Journal of Urban Economics Vol. 42 pp261-284.

Cragg, M and Kahn, M (1999) Climate Consumption and Climate Pricing from 1940-1990 Regional Science and Urban Economics Vol. 29 No. 4 pp519-539.

Cushing, B (1987) A Note on Specification of Climate Variables in Models of Population Migration Journal of Regional Science Vol. 27 pp641-649.

Englin, J (1996) Estimating the Amenity Value of Rainfall Annals of Regional Science Vol. 30 No. 3 pp273-283.

Graves, P (1980) Migration and Climate Journal of Regional Science Vol. 20 pp227-237.

Hoch, I and Drake, J (1974) Wages Climate and the Quality of Life Journal of Environmental Economics and Management Vol. 1 No. 3 pp268-265.

Hoehn J, Berger, M, and Blomquist, M (1988) A Hedonic Model of Wages, Rents and Amenity Values Journal of Regional Science Vol. 27 No. 4 pp605-620.

Il Sole 24 Ore del Lunedi (1991-5) Il Check Up delle Province 30th December 1991, 28th December 1992, 27th December 1993, 19th December 1994 and 18th December 1995, Milan, Italy.

Leemans R and Cramer W (1991) The IIASA Database for Mean Monthly Values of Temperature, precipitation and Cloudiness on a Global Terrestrial Grid The International Institute for Applied Systems Analysis Research Report RR-91-18 Laxenburg: Austria.

Maddala, G (1977) Econometrics McGraw-Hill: Singapore.

Maler, K-G (1977) A Note on the Use of Property Values in Estimating Marginal Willingness to Pay for Environmental Quality Journal of Environmental Economics and Management Vol. 4 No. 4 pp355-369.

Nordhaus, W (1996) Climate Amenities and Global Warming in Climate Change: Integrating Science, Economics, and Policy, Nakicenovic, N, Nordhaus, W Richels, R and Toth, F (eds.) IIASA CP-96-1 pp3-45. 
Palmquist, R (1991) Hedonic Methods in Measuring the Demand for Environmental Quality, Braden, J and Kolstad, C (editors) pp77-120 Elsevier: North Holland.

Roback, J (1982) Wages, Rents, and the Quality of Life Journal of Political Economy Vol. 90 No. 6 pp1257-1278.

Smith, K (1983) The Role of Site and Job Characteristics in Hedonic Wage Models Journal of Urban Economics Vol. 13 pp296-231.

Steinnes, D and Fisher, W (1974) An Econometric Model of Intraurban Location Journal of Regional Science Vol. 14 pp65-80.

Strazheim, M (1974) Hedonic Estimation of Housing Market Prices: A Further Comment Review of Economics and Statistics Vol. 56 No. 3 pp404-406. 